\title{
Computational Study of Lawsonia Inermis as Potential and Promising Candidate for Production of Solar Cell
}

\author{
Mansur Said, Yau Datti, Aliyu Ahmad, Tijjani Rufai Buhari, and Abdullahi Bappah Ahmed
}

\section{ABSTRACT}

Density Functional Theory (DFT) plays a vital role in the study of organic materials. Lawsonia inermis is identified among the promising organic candidates to replace toxic and expensive solar cell material. The present study reported step by step computational procedure used to exposed the beauty of the organic solar cell candidate using Gaussian09 software. Stability check, optimization at different basis set, Homo-Lumo, band gap and Infrared spectrum (IR) at different medium were reported. It was found that the ground state energy, Homo-Lumo at both vacuum and Medium, band gaps, were found to be $\mathbf{- 1 6 6 0 7 . 3 7 1 7 5 7 4} \mathrm{eV},-\mathbf{7 . 4 3 1} \mathrm{eV}-\mathbf{- 3 . 5 8 4}$ $\mathrm{eV}$ (Vacuum) -7.311 eV -3.515 eV (Medium) 3.847 eV (Vacuum) $3.79 \mathrm{eV}$ (Medium) respectively. For the IR it was found that there is shift and increase in the intensity due to the solvent effect on the material. These results were compared with the literature and are in agreement. It can be concluded that the Lawsonia inermis at solvent medium can enhance smooth and easier electron hole transport by looking at the band gap and hence it can and will be a good candidate organic material for solar cell production.

Keywords: Lawsone, Ground energy, Homo-Lumo, band gap and IR.
Published Online: February 24, 2021

ISSN: $2684-4478$

DOI : 10.24018/ejchem.2021.2.1.47

\section{Mansur Said*}

Physics Department, Yusuf Maitama Sule University, Nigeria.

(e-mail: msaid@ ${ }^{@}$ wu.edu.ng)

Yau Datti

Chemistry Department, Yusuf Maitama

Sule University, Nigeria.

(e-mail: yaudatti@ gmail.com)

Aliyu Ahmad Nuhu

Biological Science Department, Yusuf

Maitama Sule University, Nigeria.

(e-mail: aliyuanuhu@ yahoo.com)

Tijjani Rufai Buhari

Biological Science Department, Yusuf

Maitama Sule University, Nigeria.

(e-mail: trbuhari@yahoo.com)

Abdullahi Bappah Ahmed

Physics Department, Gombe State

University, Nigeria.

(e-mail: garkuwaz@yahoo.com)

*Corresponding Author

\section{INTRODUCTION}

Discovery of biodegradable commodities as one of the potential future substitutes of the usual toxic materials have encourage both theorist and experimentalist to search for more organic material. Because of their non-toxic, noncarcinogenic and biodegradable nature, natural products extracted from different flora and fauna are thought to be healthy [1]-[3]. Environmental pollutions result from the excess use of potentially toxic metals like lead $(\mathrm{Pb})$ and other metals; As, $\mathrm{Cd}, \mathrm{Hg}$ etc. or essential metals; $\mathrm{Cu}, \mathrm{Zn}, \mathrm{Fe}$ and $\mathrm{Mn}$ when their intake is excessively elevated. Increase in energy demand, depletion of fossil fuels and other global warming forced for searching an alternative substitute of toxic materials.

Lawsonia inermis Linn (Family: Lythraceae) commonly known as henna is an evergreen medium sized shrub or small tree 2-6 $\mathrm{m}$ in height, which may be spiny. It is mainly present in subtropical and tropical areas and is used as cosmetic and textile dye, medicine, fodder, timber, fibers, and fuel in different parts of the world. Lawsonia inermis is identified among the promising organic candidates to replace toxic and expensive solar cell material. The component of the natural dye (henna), extracted from the leaves of Lawsonia alba and
Lawsonia inermis, is 2-hydroxy-1,4-naphthoquinone, commonly known as Lawsone. In the cosmetic industry, Lawsone has been used as a dye for coloring hair, nails and skin [4]. It is also used as a detection reagent for finger marks. It is possible to use Lawsone as an electron mediator in biochemical fuel cells [9]. Lawsone molecules form a polymeric structure through the bonding of $\mathrm{O}-\mathrm{H} \cdots \mathrm{O}$ hydrogen. It is a redox active molecule and can be reversibly converted by electron/s acceptance or removal to form naphthosemiquinone and catechol. The most important characteristic of the Lawsone molecule is that it absorbs about 400-600 nm of visible light. It has been shown theoretically that by intermolecular hydrogen bonding there is percolation of electron density in lawsone molecules.

Recently, density functional theory (DFT) method, have performed to evaluated chemical properties, Subsequently, the study of the electronic and molecular properties is one of the greater importance that helps to investigate the mechanism of the photo sensitivity of lawsone compounds. In order to study electronic properties such as electron affinity (EA), hardness $(\eta)$, softness (S), electronegativity $(\chi)$ and electrophilic index $(\omega)$, density functional theory (DFT) was used. It constructs and analyzes the frontier molecular orbitals (FMOs) and energy band energies. The Molecular Electrostatic Potential (MEP) has shown that using natural 
bond orbital (NBO) analysis, the reactive site for electrophilic and nucleophilic attacks and charge delocalization is characterized. State Density (DOS), Projected State Density (PDOS) and Orbital Projected State Density (OPDOS) are interpreted for occupied and unoccupied orbital molecules [37].

The time-dependent density functional theory (TD-DFT) method has been extensively applied in the literature to determine the UV-Vis spectral characteristics of several organic dye molecules [7]-[12]. Using the TD-DFT method [13], [14], various dye sensitizers for DSSC have also recently been investigated. In addition, the solvent effect for the accurate prediction of transition energies of excited state molecules has been successfully explored by the TD-DFT calculations [7]. The key principle behind the current computational analysis is to gain better insights into the lawsone's electronic and spectral characteristics. Various derivatives of 1,4-napthoquinone (1,4-NQ) dye have been studied by Per Pète et al. [10] using the TD-DFT process. Considering different base sets, they studied the absorption spectrum of 1,4-NQ dyes and found that the 6-311+G (2d,p) basis is sufficient for the theoretical treatment of these dyes. It was also shown that PBE0 offers a reasonably clear explanation of the systems' absorption energies [9]-[12]. The conductor polarizable continuum model (C-PCM) has been found to be very promising, in addition to reflecting the solvent effect [9]-[10]. Henna dye has previously been investigated in solar cells sensitized to $\mathrm{TiO}_{2}$ dependent dye [15]. Since this dye absorbs light at three different wavelengths, namely 287,330 and $458 \mathrm{~nm}$, in the UV-Visible range, it can theoretically act as a light-absorbing dye and can thus contribute to photo-response extension. We have successfully manufactured a lawsone, one of the components of the Henna dye, sensitized $\mathrm{ZnO}$ photoanode in the current investigation and studied their system efficiency. In addition, TD-DFT has studied the spectral characteristics of lawsone in both vacuum and ethanol. Khalil et al, 2011[27], stated that in the UV-vis and near IR region of the solar spectrum, Bahrain and Yemani Henna extract experimentally exhibit high levels of absorption. The report shows that in terms of higher photocurrency and open-circuited voltage and higher photovoltaic cell-based performance, Bahraini henna has higher light harvesting efficiency than Yemani. May Win et al [18] stated that the excitation under solvent solution of lawsone was greater than that in the vacuum. Zulkifli et al 2017 [25] stated that due to its presence of hetroatomics such as oxygen and hydrogen, Lawsonia inermis green material formed as a corrosion inhibitor for aluminum in the marine environment and became active centers for absorption process. Mirella et al 2019 [26] stated that the structural stability of the compound of lawsone and its derivatives has a high excitation and absorption wavelength value that demonstrates strong potential application to solar cells.

The present work offers a detailed DFT study on the photo sensitivity of the compound Lawsonia inermis. The study covers building compound lawsone, testing stability, optimizing the structure with B3LYP at different base sets, measuring its electronic properties, infrared spectrum, for various mediums and solvents.

\section{COMPUtational Procedure}

Using hybrid functional B3LYP, ground state geometry optimization of vacuum lawsone is performed with DFT at different base sets; STO, 3-21G, 6-31G and 6-311G [9]. In order to ensure that the obtained structure is minimal on the potential energy surface, the frequency measurement is performed with optimized geometry. In addition, this optimized geometry is used for the non-equilibrium TDDFT/B3LYP/6-311+G(d,p) method of calculating the UVVis spectrum. The solvent effect is implicitly considered in the Default, IEFPCM, I-PCM, and SCI-PCM models. The 3dimensional mapping of molecular orbitals is achieved using the B3LYP/6-311+G(d,p) basis set. At the B3LYP/6$311+\mathrm{G}(\mathrm{d}, \mathrm{p})$ theory stage in vacuum and other solvents, the highest occupied molecular orbital (HOMO) and lowest unoccupied molecular orbital (LUMO) energies are measured. All the calculations in the present work are achieved by programming Gaussian 09 [17].

\section{RESUlT AND DISCUSSION}

\section{A. Building and Stability Check}

The structure was built using gauss view and the letter runs for stability check at restricted hatree fork (RHF) and basis set of 3-21G. The stability was further checked with optimized functions and energies were calculated.

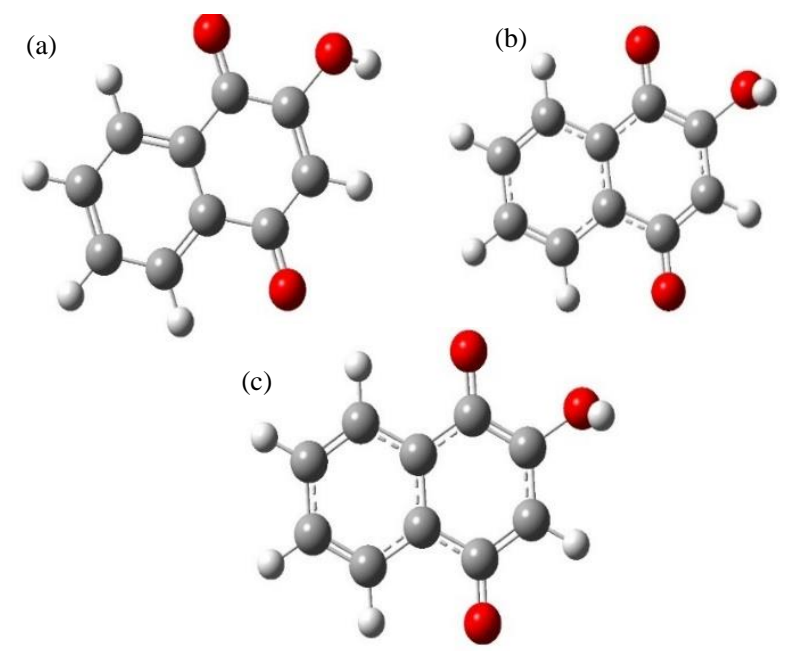

Fig. 1. Lawsone structure (a) initial structure (b) stable structure (c) optimizes and stable structure/

For the stability check, it was observed that there is appearance of some partial bond in the first benzene rings which shows that the structure is tightly stable and the bonding between the atoms are strong. It was also indicated that the energies obtain are $-16417.01 \mathrm{eV}$ and $-16418.61 \mathrm{eV}$ for single stability and opt_stability respectively and is an indication that the structure is approaching the ground state.

\section{B. Optimization}

Optimization process helped in determine the best set up for preparing the structure and hence produced the best. Fig. 2 shows the optimization steps for the two media: vacuum and that of solvent. For the vacuum medium, it was observed that the structure was dropped down by losing energy and then later stabilized. However, for the solvent due to its effect, 
the structure had increase in energy and then dropped down and the stabilized.

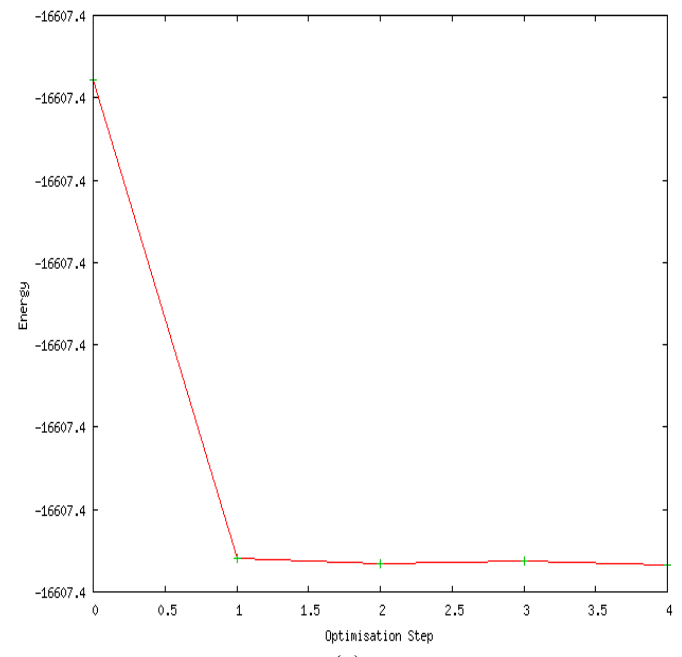

(a)

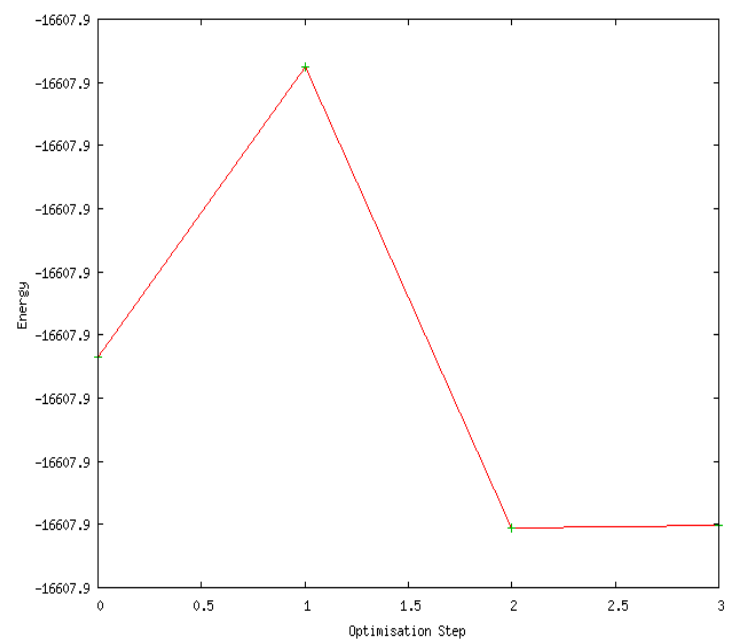

(b)

Fig. 2. Energy Optimization steps of Lawsonia inermis (a) Vacuum (b) Medium.

Table 1 is the step by step procedure performed to determine the lowest energy of the Lawsonia inermis. The procedure was carried from the lowest basis set STO-3G to the highest basis set $6-311 \mathrm{G}$. It was observed that the is significant effect in time, energy, and dipole moment.

Quantum Mechanics (QM) based continuum models are so popular in determining the solvent effects. Gaussian 09 contains different model; continuum Polarized Continuum Model (CPCM), Polarized Continuum Model (PCM), Integral Equation Fourier Polarized Continuum Model (IEFPCM), and Integral Continuum Model (I-PCM). These models were tested using solvents; Acetonitrile, DMSO, Ethanol, Methanol, Nitromethane and Water. Table 2 shows the effect of solvent and model on Lawsonia inermis organic material. For each model the result of Homo Lumo using these solvents were presented and compared with the literature.

The frontier molecular orbital (MO) energies including highest-occupied molecular orbital (HOMO), lowest unoccupied molecular orbital (LUMO) and energy gap of lawsone were calculated at different condition as shown in
Table 2. The result of vacuum was first calculated and the Homo, Lumo and Energy gap were -7.48175369 eV, $3.50590706 \mathrm{eV}$ and $3.98 \mathrm{eV}$. For the medium, the Homo, Lumo and energy gap at I-PCM were -7.311139 eV, 3.515159 eV and 3.79eV as shown in Fig. 3. Also, it was observed that there is shift in the MO due to the solvent effect as shown in Fig. 4 a, b. The shift narrows the energy gap and hence electrons can easily move to the valance band.

The frontier molecular orbital (MO) energies including highest-occupied molecular orbital (HOMO), lowest unoccupied molecular orbital (LUMO) and energy gap of lawsone were calculated at different condition as shown in Table 2. The result of vacuum was first calculated and the Homo, Lumo and Energy gap were -7.48175369 eV, $3.50590706 \mathrm{eV}$ and $3.98 \mathrm{eV}$. For the medium, the Homo, Lumo and energy gap at I-PCM were -7.311139 eV, 3.515159 eV and 3.79eV as shown in Fig. 3. Also, it was observed that there is shift in the MO due to the solvent effect as shown in Fig. 4 a, b. The shift narrows the energy gap and hence electrons can easily move to the valance band.

TABLE1: OPTIMIZATION AT DIFFERENT BASIS SET AND RB3LYP

\begin{tabular}{cccccc}
\hline S/N & Basis Set & $\begin{array}{c}\text { Energy } \\
\text { (a.u.) }\end{array}$ & $\begin{array}{c}\text { Energy } \\
\text { (eV) }\end{array}$ & $\begin{array}{c}\text { Dipole_moment } \\
\text { (Debye) }\end{array}$ & $\begin{array}{c}\text { Time } \\
\text { (min) }\end{array}$ \\
\hline 1 & STO-3G & -602.4469754 & -16393.3801845 & 0.3583 & 24.48 \\
2 & $3-21 G$ & -606.9655218 & -16516.3358156 & 0.3741 & 29.17 \\
3 & $6-31 G$ & -610.1624536 & -16603.3285641 & 0.8219 & 35.15 \\
4 & $6-311 G$ & -610.3110385 & -16607.3717574 & 0.8311 & 89.48 \\
\hline
\end{tabular}

TABLE 2: THE HiGHEST OCCUPIED MOLECULAR ORBITAL ENERGIES $\left(E_{\text {Homo }}\right)$, THE LOWEST UNOCCUPIED MOLECULAR ORBITAL ENERGIES $\left(E_{\text {LUMO }}\right)$, THE

\begin{tabular}{|c|c|c|c|c|c|c|c|c|c|c|c|c|c|}
\hline \multirow{2}{*}{$\begin{array}{c}\text { Model } \\
\text { Solvent } \\
\end{array}$} & \multicolumn{3}{|c|}{ CPCM } & \multicolumn{3}{|c|}{ PCM } & \multicolumn{3}{|c|}{ IEFPCM } & \multicolumn{3}{|c|}{ I-PCM } & \multirow{2}{*}{ Ref } \\
\hline & Homo & Lumo & $E_{g}$ & Homo & Lumo & $E_{g}$ & Homo & Lumo & $E_{g}$ & Homo & Lumo & $E_{g}$ & \\
\hline Acetonitrile & -7.430 & -3.586 & 3.843 & -7.43 & -3.57 & 3.861 & -7.432 & -3.571 & 3.861 & -7.311 & -3.515 & 3.79 & $\begin{array}{c}{[18]} \\
4.09 \mathrm{eV}\end{array}$ \\
\hline DMSO & -7.429 & -3.597 & 3.842 & -7.43 & -3.57 & 3.859 & -7.431 & -3.572 & 3.859 & -7.311 & -3.515 & 3.79 & $\begin{array}{c}{[19]} \\
3.06 \mathrm{eV}\end{array}$ \\
\hline $\begin{array}{l}\text { Ethanol } \\
\text { Methanol }\end{array}$ & $\begin{array}{l}-7.431 \\
-7.430\end{array}$ & $\begin{array}{l}-3.584 \\
-3.586\end{array}$ & $\begin{array}{l}3.847 \\
3.844\end{array}$ & $\begin{array}{l}-7.43 \\
-7.43\end{array}$ & $\begin{array}{l}-3.57 \\
-3.57\end{array}$ & $\begin{array}{l}3.865 \\
3.862\end{array}$ & $\begin{array}{l}-7.434 \\
-7.433\end{array}$ & $\begin{array}{l}-3.569 \\
-3.570\end{array}$ & $\begin{array}{l}3.865 \\
3.862\end{array}$ & $\begin{array}{l}-7.311 \\
-7.311\end{array}$ & $\begin{array}{l}-3.515 \\
-3.515\end{array}$ & $\begin{array}{l}3.79 \\
3.79\end{array}$ & \\
\hline $\begin{array}{c}\text { Nitrometha } \\
\text { ne }\end{array}$ & -7.430 & -3.586 & 3.843 & -7.43 & -3.57 & 3.857 & -7.432 & -3.571 & 3.851 & -7.311 & -3.515 & 3.79 & \\
\hline Water & -7.428 & -3.588 & 3.840 & -7.43 & -3.57 & 3.857 & -7.430 & -3.573 & 3.857 & -7.311 & -3.515 & 3.79 & \\
\hline
\end{tabular}




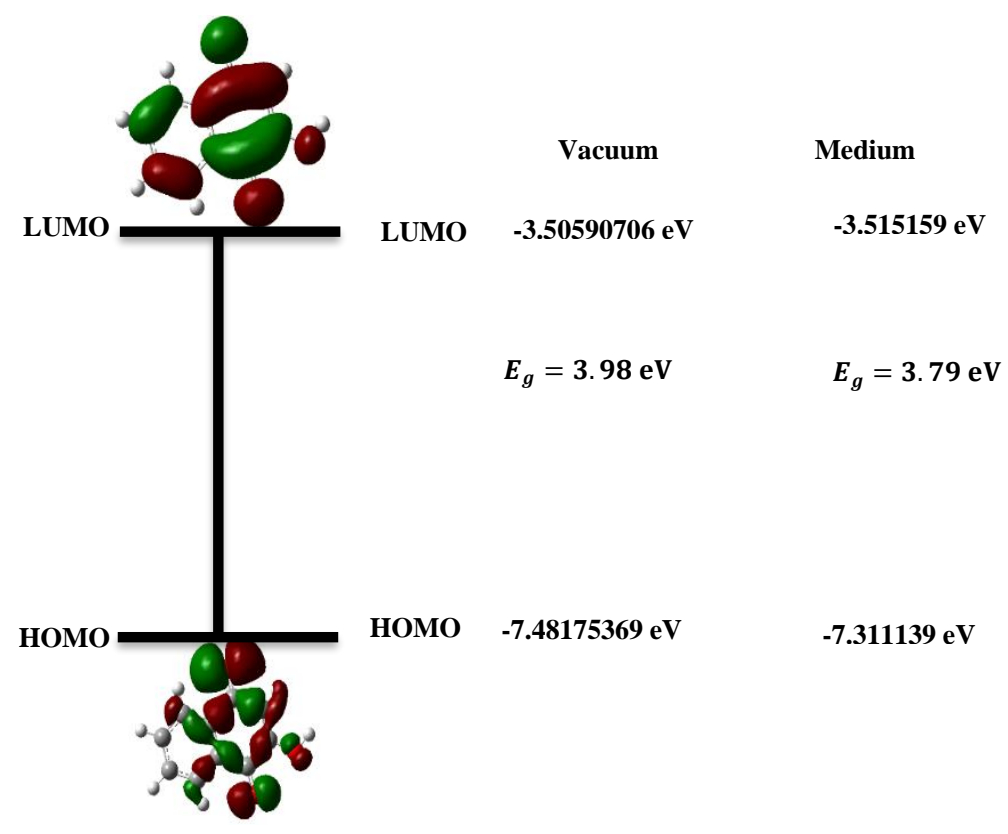

Fig. 3. Lawsonia inermis energy gap at different medium.

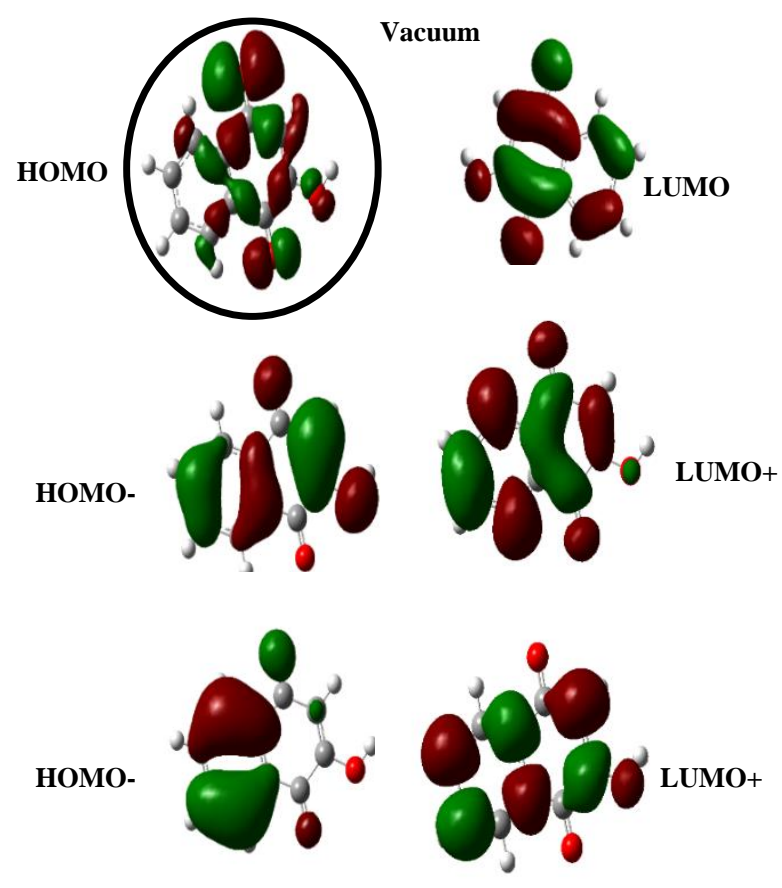

(a)

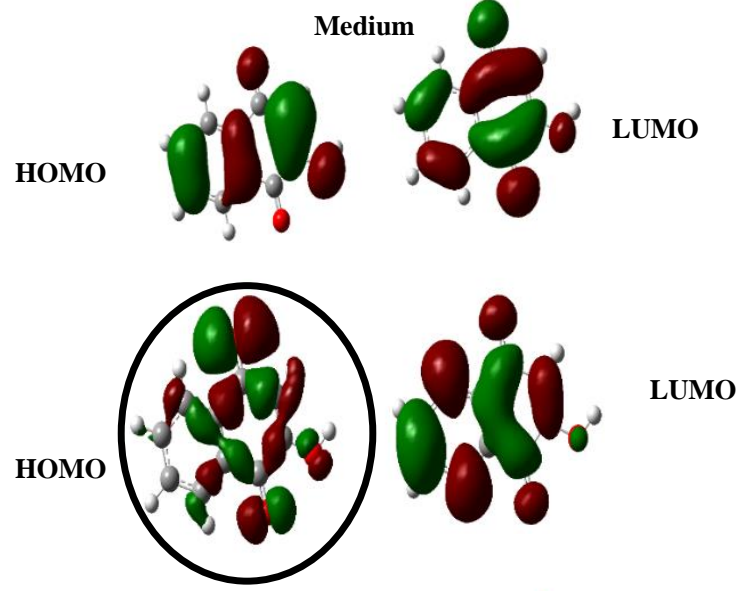

HOMO
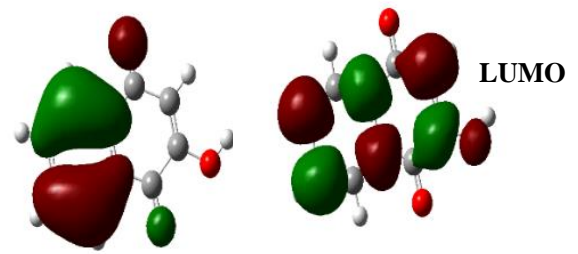

(b)

Fig. 4. Molecular Orbital of Lawsone at (a) vacuum (b) Medium.

Fig. 5 shows the electronic Density of State of Lawsonia inermis at vacuum and medium. It was found that due to the solvent effect there are more P-configuration than in the vacuum and this resulted in the narrowing the energy band gap and hence electron transport occurs easily. Also, at energy range between $-10 \mathrm{eV}$ to $-15 \mathrm{eV}$, there is change in electron population due to the solvent effect as observed in the figure. Solvent effect shows promising performance in the production of Lawsonia inermis as organic solar cell.

Infrared spectroscopy (IR) is the qualitative aspects of infrared spectroscopy are one of the most powerful attributes of this diverse and versatile analytical technique. And is a type of absorption spectroscopy that is used to determine the functional groups present (or absent) in a molecule. It was observed that there is observed that there is great effect due to the solvent presence as shown in the Fig. 5 below. This causes the shift in the presence of the functional group as shown in table 3 . It was observed that model plays vital role in the shifting of the peaks and increase of intensity of the functional group. These functional group were also observed by [24], and [21]-[23]. 

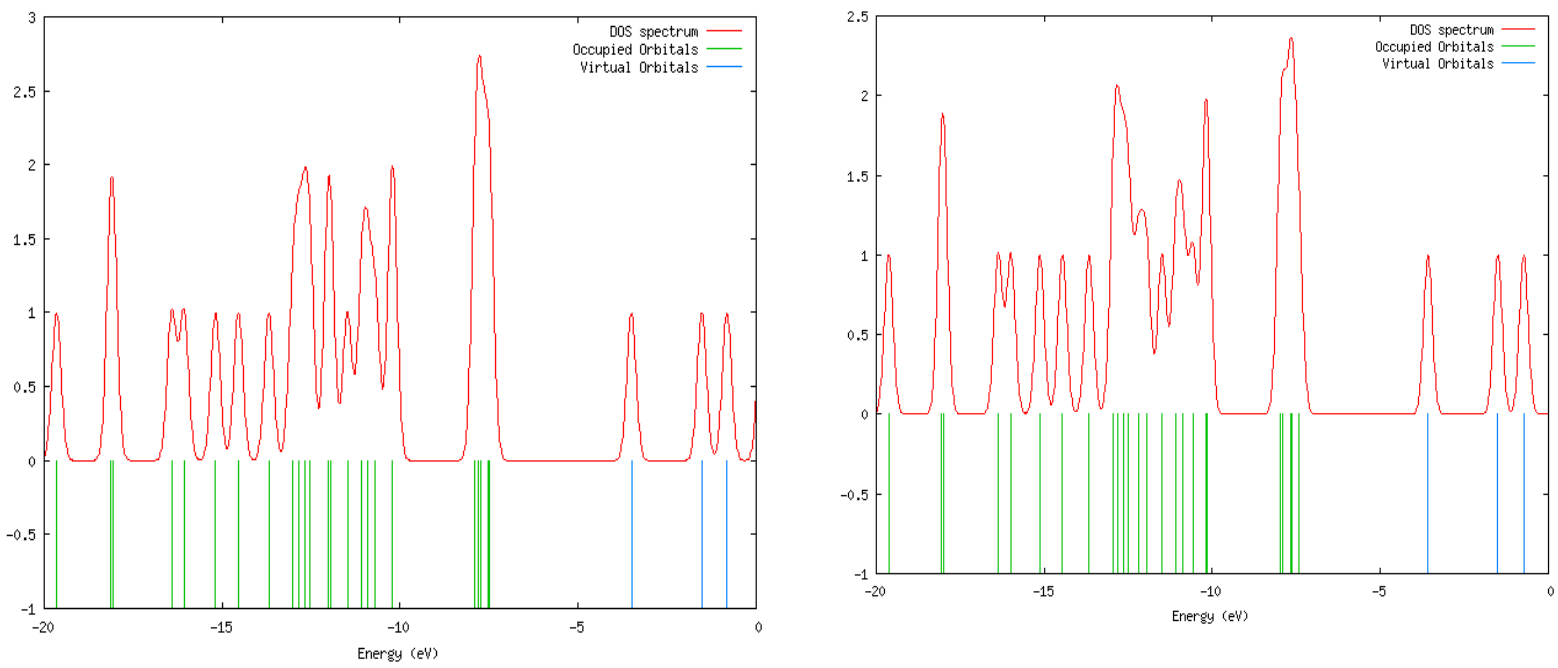

Fig. 5. Electron density population of Lawsonia inermis (a) Vacuum (b) Medium.
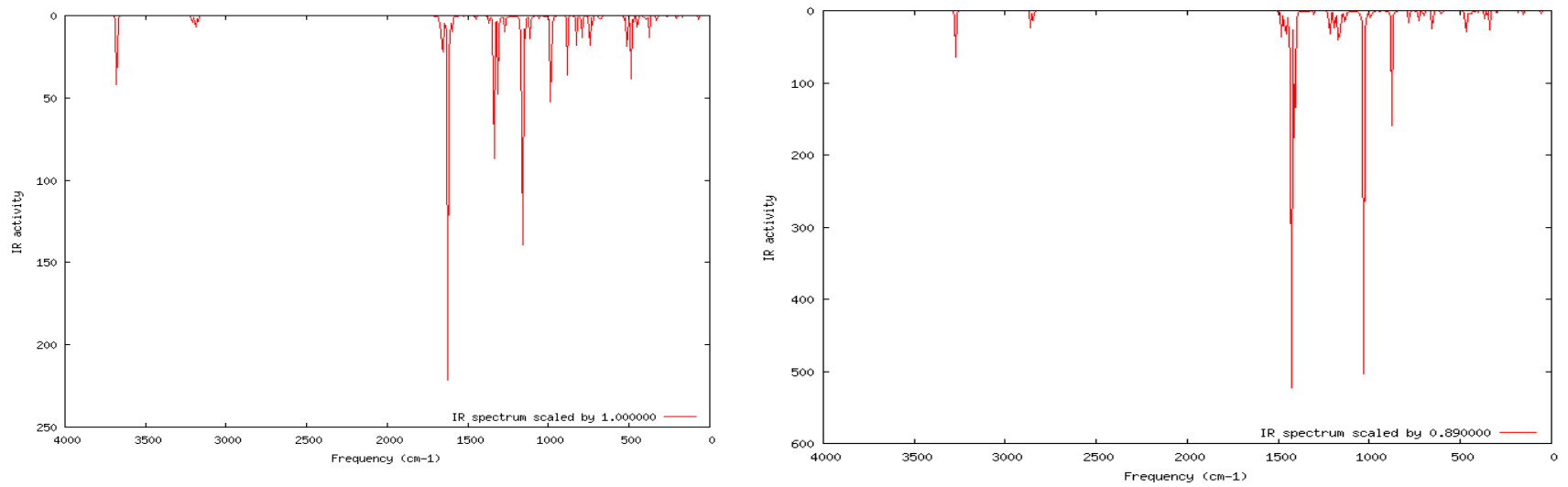

Fig. 6. Infrared Spectrum of Lawsonia inermis (a) Vacuum (b) Medium.

TABLE 3: INFRARED SPECTROSCOPY OF LAWSONIA INERMIS IN VACUUM AND IN MEDIUM USING I-PCM MODEL AND ETHANOL SOLVENT

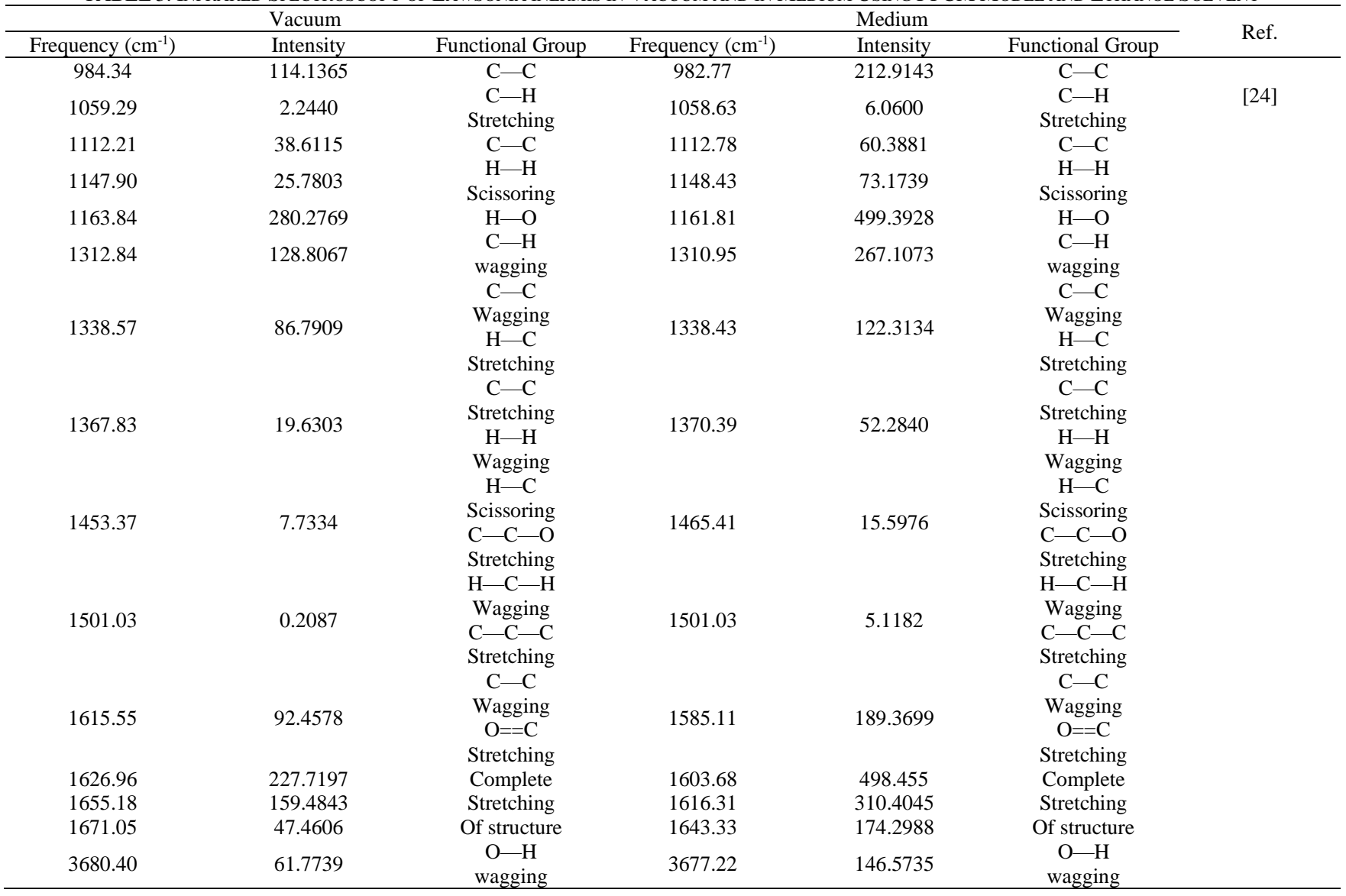




\section{CONCLUSION}

Density functional theory studies was carried out to study the potential promising of Lawsonia inermis as organic solar cell. The study detailed the step by step procedure of stability, optimization and, IR studies of the lawsone structure using Gaussian09 software. In the studies the energies obtained for the ground state using B3LYP/6-311G was found to be $16607.3717574 \mathrm{eV}$ at $89.48 \mathrm{~min}$. It was found that due to the effect of solvent, the studied found that the material can and will be used as solar cell candidate. Also, it was reported solvent effect narrows the band gas to $3.79 \mathrm{eV}$ which lags by $0.29 \mathrm{eV}$ as reported by [18] and leads by 0.73 as reported by [19]. This narrowing in the band gas was as a result of exchange in the molecular orbital in the Homos as shown in Fig. 4 a, b. However, for the IR studies shows that shifting and increasing in the intensity was due to effect cause by solvent and model as well.

\section{ACKNOWLEDGEMENT}

This paper was part of the research sponsored by Tetfund through Yusuf Maitama Sule University Kano. We thank the Nigerian Government for introducing the scheme in order to promote research culture and linked relations with industries. We also like to express our appreciation to the management of Yusuf Maitama Sule University Kano for their support.

\section{REFERENCES}

[1] D. Prabhu and P. Rao, "Coriandrum sativum L. - a novel green inhibitor for the corrosion inhibition of aluminium in $1.0 \mathrm{M}$ phosphoric acid solution," Journal of Environmental Chemical Engineering, vol. 1, no. 4, pp.676-683, 2013.

[2] S. Ali, T. Hussain, and R. Nawaz, "Optimization of alkaline extraction of natural dye from Henna leaves and its dyeing on cotton by exhaust method,"Journal of Cleaner Production, vol. 17, no. 1, pp. 61-66, 2009.

[3] F. Suedile, F. Robert, C. Roos, and M. Lebrini, "Corrosion inhibition of zinc by Mansoa alliaceaplant extract in sodium chloride media: extraction, characterization and electrochemi-cal studies,' Electrochimica Acta, vol. 133, pp. 631-638, 2014.

[4] O. Moullet, J. Dreyer, Biochem. J.1994, 300, 99-106.

[5] K. Tanaka, R. Tamamushi, T. Ogawa, J. Technol. Biotech. 1985, 35B, 191-197.

[6] N. R. Dhumal, A. V. Todkary, S. Y. Rane, S. P. Gejji, Theor. Chem. Acc. 2005 113, 161-166.

[7] D. Jacquemin, E. A. Perpète, G. E. Scuseria, I. Ciofini, C. Adamo, J. Chem. Theory Comput. 2008, 4, 123-135.

[8] K. A. Nguyen, J. Kennel, R. Patcher, J. Chem. Phys.2002, 117, 71287136.

[9] D. Jacquemin, J. Preat, V. Wathelet, E. A. Perpète, Chem. Phys. 2006, 328, 324-332.

[10] E. A. Perpète, C. Lambert, V. Wathlet, J. Preat, D.Jacquemin, Spectrochim. Acta Part A2007, 68, 1326-1333.

[11] F. Labat, T. Le Bahers, I. Cliofini, C. Adamo, Acc. Chem. Res. 2012, $45,1268-1277$

[12] A. Adegoke, J. Wang, J. Leszczynski, Chem. Phys. Lett.2012, 532, 63 67.

[13] P. Ekanayake, M. R. R. Kooh, N.T.R.N. Kumara, A. Lim, M. I. Petra, V. N. Y. C. Ming, Chem. Phys. Lett.2013, 585, 121- 75127.

[14] Y. Y. Tan, W. H. Tu, S. Manzhos, Chem. Phys. Lett. 2014, 593, 14-19.

[15] K. E. Jasim, S. Al-Dallal, A. M. Hassan, J. Nanotech. 2012, 1-6.

[16] M. Moral, G. García, A. Garzón, J. M. Granadino-Roldán, M. A. Fox, D. S. Yufit, A. Peñas, M. Melguizo, M. Fernández-Gómez, J. Phys. Chem. C 2014, 118, 26427-26439.

[17] Gaussian 09, Revision A.1, M. J. Frisch, G. W. Trucks, H. B. Schlegel, G. E. Scuseria, M. A. Robb, J. R. Cheeseman, G. Scalmani, V. Barone, B. Mennucci, G. A. Petersson, H. Nakatsuji, M. Caricato, X. Li, H. P. Hratchian, A. F. Izmaylov, J. Bloino, G. Zheng, J. L. Sonnenberg, M. Hada, M. Ehara, K. Toyota, R. Fukuda, J. Hasegawa, M. Ishida, T.
Nakajima, Y. Honda, O. Kitao, H. Nakai, T. Vreven, J. A. Montgomery, Jr., J. E. Peralta, F. Ogliaro, M. Bearpark, J. J. Heyd,E. Brothers, K. N. Kudin, V. N. Staroverov, R. Kobayashi, J. Normand, K. Raghavachari, A. Rendell, J. C. Burant, S. S. Iyengar, J. Tomasi, M. Cossi, N. Rega, J. M. Millam, M. Klene, J. E. Knox, J. B. Cross, V. Bakken, C. Adamo, J. Jaramillo, R. Gomperts, R. E. Stratmann, O. Yazyev, A. J. Austin,R. Cammi, C. Pomelli, J. W. Ochterski, R. L. Martin, K. Morokuma, V. G. Zakrzewski, G. A. Voth, P. Salvador, J. J. Dannenberg, S. Dapprich, A. D. Daniels, Ö. Farkas, J. B. Foresman, J. V. Ortiz, J. Cioslowski, D. J. Fox, Gaussian, Inc., Wallingford CT, 2009.

[18] May Win Han, Piyasiri Ekanayake, Lim Chee Ming, and Voo Nyuk Yoong, DFT/TD-DFT Studies on the Lawsone (Henna) as a Photosensitizer for Dye- Sensitized Solar Cells. Applied Mechanics and Materials. ISSN: 1662-7482, Vols. 789-790, pp 56-60. 2015. doi:10.4028/www.scientific.net/AMM.789-790.56.

[19] Shubhangi S. Khadtare, Sandesh R. Jadkar, Sunita Salunke-Gawali and Habib M.Pathan, Lawsone Sensitized ZnO Photoelectrodes for Dye Sensitized Solar Cells. Journal of Nano Research Vol. 24 (2013) pp 140-145.

[20] Lakshmi R., Krishnakumar G., Lyjo K. Joseph and K. S. Sreelatha, Jinchu I., Lawsone dye complex: an efficient sensitizer for Dye Sensitized Solar Cell. International Conference on Electrical, Electronics, and Optimization Techniques (ICEEOT) - 2016.

[21] Gans, P. (1975) Vibrating Molecules: An Introduction to the Interpretation of Infrared and Raman Spectra, Chapman \& Hall, London. Pp 126-133.

[22] Coates, J. (2000). Interpretation of Infrared Spectra: A Practical Approach Encyclopedia of Analytical Chemistry R.A. Meyers (Ed.) O John Wiley \& Sons Ltd, Chichester. Pp.10815-10837.

[23] Colthrup, NB., Daly, LH., and Wiberley, SE. (1990). Introduction to Infrared and Raman Spectroscopy, Academic Press, San Diego, CA, Pp $1-73$.

[24] Yau Datti and Bilkisu Mukhtar (2016) Determination of the concentrations of $\mathrm{Cu}, \mathrm{Zn}$ and $\mathrm{Fe}$ in five selected leafy vegetables used as relish in Kano State, Nigeria. World Journal of Advanced Research and Reviews, 07(02), 056-062.

[25] F. Zulkifli, Nora'aini Ali, M. Sukeri M. Yusof, Wan M. Khairul, Rafizah Rahamathullah, M. I. N. Isa, and W. B. WanNik (2017) The Effect of Concentration ofLawsonia inermisas a Corrosion Inhibitor for Aluminum Alloy in Seawater. Hindawi Advances in Physical Chemistry Volume 2017, Article ID 8521623,12 pages. https://doi.org/10.1155/2017/8521623.

[26] Mirella Fonda Maahury, Muhamad A. Martoprawiro (2019) Computational calculation potency of lawsone and its Derivatives as active material in dye-sensitized solar cell. Jurnal Kimia Mulawarman Volume 17 Nomor Kimia FMIPA Unmul. P-ISSN 1693-5616.

[27] Khalil EbrahimJasim, Shawqi Al-Dallal, and Awatif M. Hassan (2012) Henna (Lawsonia inermisL.) Dye-Sensitized Nanocrystalline Titania Solar Cell. Hindawi Publishing Corporation Journal of Nanotechnology, Article ID 167128,6pages. doi:10.1155/2012/167128.

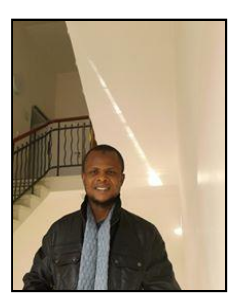

Mansur Said is an indigene on Kano Nigeria had my $\mathrm{PhD}$ Sandwich at Fritz Haber Institute Theory department Berlin Germany. He obtained his $\mathrm{PhD}$, M.Sc, and B.Sc Physics at Bayero University Kano Nigeria. Since then, he has been working with Yusuf Maitama Sule University Kano.

Mansur has specialized in Physics of Material Science and conversant with programing tools such as Python, Fortran and Java. As at now He has published more than 40 articles at both local and international journal and are working on more. His dream was to collaborate with outside researchers to share and contribute to the development or solving global problems. He as supervise both $\mathrm{PhD}, \mathrm{M}$.Sc and B.Sc student across Northern Nigerian Universities. However, he has been working with international computational software's such as Fritz Haber Institute ab-inition molecular code (Fhi-aims), Quantum Espresso, Siesta, Orca e.t.c.

His door is always open for collaboration or seeking clarifications with regards to his area of specialization. 


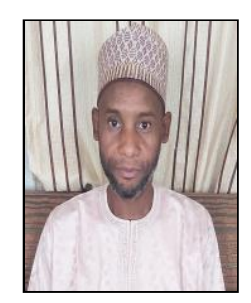

Tijjani Rufai Buhari was born in Kano state Nigeria on July 11968 . He started his early primary education from 1975 to 1981 and enrolled into secondary school from 1981 to 1986 in Kano state. He obtained his Bachelor of science degree (hon) in applied biology in 1992 from Bayero University Kano Nigeria and later the Master's degree in ecology in 1998 from the same University. Being a lecturer and ecologist, the global environmental problem motivated him to further his study and research potentials in the areas of ecotoxicology at university Putra Malaysia in 2007 where he graduated in 2012. In 1996 he was employed as a classroom officer with ministry of education Kano state, where he joined Kano state Polytechnics from 1997 to 2013 as a lecturer rising to the position of Senior Lecturer. He then joined Yusuf Maitama Sule University Kano as a lecturer where he is currently the Dean Faculty of Science

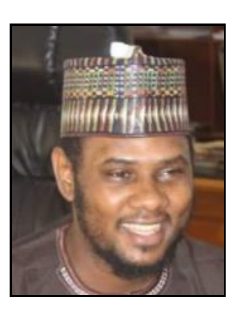

Abdullahi Bappah Ahmed is an active and vibrant researcher and Assistant Professor in the Gombe State University Gombe. Gombe State Nigeria. He obtained his first degree at Gombe State University, Gombe Nigeria and M.Sc and PhD from People's Friendship University Russia. $\mathrm{He}$ specialized theoretical condense matter physics. He published more than 40 articles at both local and international journal. He is currently supervising both M.Sc and PhD student and Gombe state University.

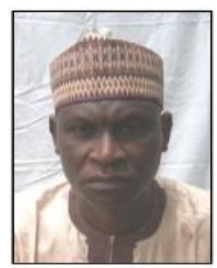

Dr. Yau Datti obtained his Ph.D in the year 2015 from Bayero University, Kano, Nigeria. He is currently working as a lecturer with Yusuf Maitama Sule Univeristy Kano (formerly Northwest University,Kano) Nigeria. He has published research papers in many reputed international journals. His main research work focuses on stress biology. His main areas of my research interest are organic synthesis, natural products and drug discovery. He has 12 years of teaching and research experience.

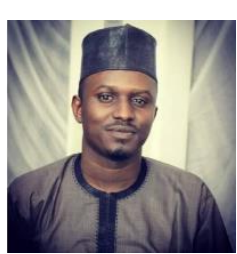

Aliyu Ahmad Nuhu is an active researcher at Biological Science Department, Yusuf Maitama Sule University Kano, Nigeria. He obtained his B.Sc and M.Sc at Bayero University Kno, Nigeria. Currently persuing his $\mathrm{PhD}$ at Federal University Dutse, Jigawa State. Published many articles and presented seminar at both local and international conferences. His ambition is to collaborate with both local and international scholars around the globe. 